\title{
LĖTINĖS DILGĖLINĖS YPATUMAI
}

\author{
EDITA GASIŪNIENĖ, DOC. DR. BRIGITA ŠITKAUSKIENE்
}

KMU PULMONOLOGIJOS IR IMUNOLOGIJOS KLINIKA

\begin{abstract}
Reikšminiai žodžiai: lètinè dilgèlinė, antihistamininiai vaistai, putlioji ląstelè.
Santrauka. Lètinè dilgèlinè (LD) labai smarkiai blogina gyvenimo kokybę, nes sutrinka miegas, atsiranda nuovargis, socialinè izoliacija, emocinių bei seksualinių sunkumų, stokojama energijos. Lètinè dilgèlinè - tai ¡̇vairialypis ligų ir būkliụ kompleksas, kuriam būdingas greitas pūkšliụ susiformavimas kasdien ar rečiau, trunkantis ilgiau nei šešias savaites. Kai kuriais atvejais sunku nustatyti priežasți, sukeliančią lètinę dilgèlinę, tada diagnozuojama lètinè idiopatinè dilgèlinè. Vis dèlto kiekvieną kartą reikia siekti nustatyti ligą sukeliančią priežasț̇, nes nuo jos atmetimo priklauso gydymo kokybè. Beveik pusei pacientų, sergančių lètine idiopatine dilgèline, nustatoma autoantikūnų, kurie skatina putliujų ląstelių degranuliaciją. Antros kartos antihistamininiai vaistai yra pirmaeiliai gydant lètinę dilgèlinę, jų saugumas ir veiksmingumas įrodytas moksliniais tyrimais.
\end{abstract}

Sergant lètine dilgèline pūkšlès su angioedema ar be jos susiformuoja greitai ir paprastai išnyksta per 1-24 valandas, dažnai kartu vargina niežulys ar deginimas, labai suintensyvėjantys naktị. Pagrindinis angioedemos požymis - gilesnių odos sluoksnių, poodžio (dažnai ir gleivinių) paburkimas, kuris dažniau esti skausmingas, o ne niežtintis, išnykstantis leečiau, per 72 val.

Lètinè dilgèlinè - viena dažniausių odos bei alerginių ligų, varginanti tiek vaikus, tiek suaugusiuosius (iki 6,7 proc.), ji pasireiškia net iki 35 proc. atopiškuc asmenų. Lètinès dilgèlinès simptomai (išbèrimas, niežulys) labai veikia pacientų gyvenimo kokybę. Dèl nuolatinio, ypač naktị suintensyvejjančio niežulio pacientai blogai miega, atsiranda lètinis nuovargis, stokojama energijos, o tai atsiliepia darbingumui. Irodyta, kad vaikai, sergantys lètine dilgèline, praranda net iki 35 proc. darbingumo, nukenčia jų dèmesio koncentravimas, lavinimosi gebejjimai. Pasikeitusi fizinè išvaizda dažnai lemia socialinę izoliaciją, atsiranda emocinių bei seksualinių sunkumų.

\section{ETIOPATOGENEZE்}

Dilgèlinès patogenezèje svarbiausios - putliosios ląstelès. Putliụjų ląstelių degranuliacija yra aktyvus metabolinis procesas, kurio metu atsipalaiduoja ịvairūs uždegimo mediatoriai (histaminas, triptazè, leukotrienai, prostaglandinai, kininai ir kt.). Po degranuliacijos putliosios ląstelès yra nejautrios stimuliavimui nuo kelių valandų iki kelių parų.

Putliụjų ląstelių degranuliaciją ir histamino išsiskyrimą gali sukelti:

- I tipo alerginè reakcija, kai alergenai ir IgE prisijungia prie FcRI receptoriu (alerginès kilmès dilgèlinè).

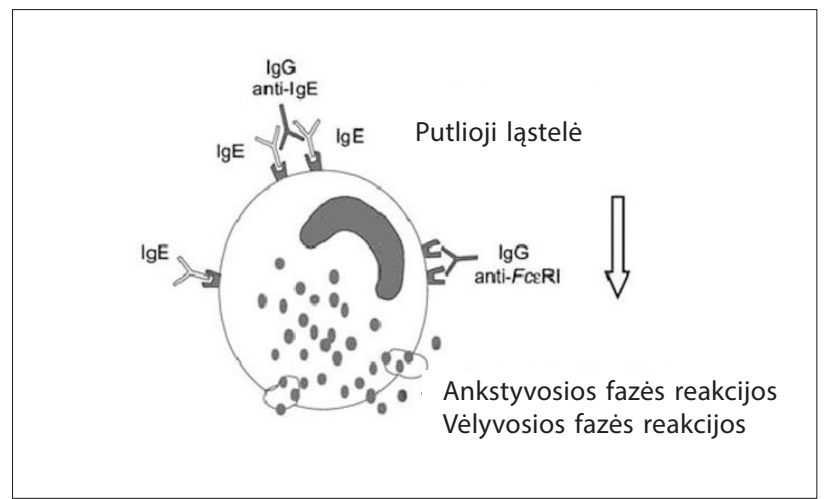

1 pav. IgG KLASĖS AUTOANTIKŨNAI PRIEŠ IgE BEI PUTLIŲJŲ LĄSTELIŲ PAVIRŠIAUS IGE RECEPTORIŲ

- Autoantikūnai prieš FcRI receptorius ar IgE (autoimuninès kilmès dilgèlinè).

- Nervu sistemos stimuliavimas - kai periferinès nervinès skaidulos sąveikauja su putliosiomis ląstelèmis, neuromediatorius $\mathrm{P}$ tiesiogiai išlaisvina histaminą (cholinerginè lètinè dilgèlinè).

- Tiesioginis histamino išsilaisvinimas - kontaktinė lètinè dilgèlinè.

Dažnu atveju lètinè dilgèlinè gali pasireikšti kaip lètinè neaiškios kilmès infekcija. Tai gali lemti ir virusinè (A, B hepatitas, lètiné viršutinių kvejpavimo takų infekcinè liga), ir bakterinė (nazofaringitas, sinusitas, $\mathrm{He}$ licobacter pylori), ir grybelinè (ypač išplitusi žarnyno kandidozè) infekcija, taip pat parazitinès, pirmuonių sukeliamos infekcijos. Svarbu išsiaiškinti, ar pacientas neserga lètinèmis uždegimo ligomis: gastritu, refliuksiniu ezofagitu, tulžies pūslès ar jos latakų uždegimu, sistemine raudonąja vilklige. Vis dažniau kalbama apie lètinès dilgèlinès ir véžio sąsają. 75-80 proc. atvejų lètinès dilgèlinès priežasties nustatyti nepavyk- 
sta - tada diagnozuojama lètiné idiopatiné dilgèlinè, tačiau bet kuriuo atveju reikia siekti išsiaiškinti tikrąsias ligą sukėlusias priežastis. Vis daugẻja duomenų, kad dalies pacientų liga yra autoimuninès kilmès, mat tyrimais nustatoma autoimuninių žymenų. 5-10 proc. pacientų kraujyje randama IgG klasès autoantikūnų prieš IgE, 35-40 proc. - putliụjų ląstelių paviršiaus IgE receptorių. Tokiais atvejais dilgèlinè yra sunkesnès eigos - aktyvesnè, silpnesnis antihistamininių vaistų poveikis, dažniau būna sisteminių ligos požymių. 4-14 proc.' dilgèline sergančių ligonių serume nustatoma autoantikūnų skydliaukès baltymams (tiroglobulinui, mikrosomoms), o maždaug pusė jų turi gūži ar sutrikusią skydliaukès funkciją.

Pati dažniausia lètinę dilgèlinę provokuojanti priežastis - fiziniai veiksniai (dermografizmas, spaudimas, šaltis, šiluma, saulè, vibracija). Lètinė dilgèlinè, sukelta fizinių veiksnių, pasireiškia pūkšlėmis bei niežèjimu po tam tikro fizinio veiksnio ir trunka nuo keliu iki 24 val. Spaudimo sukelta dilgèlinè išryškèja po 2-8 val. ir gali trukti ilgiau nei 24 val., dažniau vyrams delnų, padų, sẻdmenų srityse. Dažniausiai iš fizinių veiksnių lètinę dilgèlinę provokuoja spaudimas (dermografizmas bei spaudimo sukelta lètinè dilgèlinè); šviesa (šviesos sukelta lètinè dilgèlinè), šaltis (šaltas vanduo, šalti daiktai) bei šiluma. Šalčio sužadinama lètine dilgèline gerokai dažniau serga jaunos moterys; simptomus išprovokuoja šaltas (žemesnès nei kūno temperatūra) vanduo, daiktai, netgi šaltas oras. Šviesos bangos, kuriuc ilgis $280-760 \mathrm{~nm}$, taip pat gali sukelti lètinę dilgèlinę (saulès sužadinta lètinè dilgèlinè). Šilumos sukeliama lètinè dilgèlinè pasireiškia tada, kai žmogaus kūnas yra tiesiogiai paveikiamas šilto oro ar šiltų daiktų, slenkstinè temperatūra svyruoja tarp $38^{\circ} \mathrm{C}$ ir $50^{\circ} \mathrm{C}$. Šilumos bei vibracijos sužadinama lètinè dilgèlinè pasitaiko gan retai.

Gydytojo praktikoje pasitaiko ir kitų formų lètinès dilgèlinès atvejų: vandens, cholinerginè, kontaktinè, fizinio krūvio anafilaksija/dilgèlinè. Cholinerginè lètiné dilgèlinè pasireiškia, kai pakyla šerdinè kūno temperatūra. Dažniausios priežastys: fiziniai pratimai, pasyvus kaitinimasis (pirtis, karšta vonia), emocinis stresas, rečiau - šiltas ar aštrus maistas, alkoholis. Cholinerginė lètinè dilgèlinė gana dažnai (apie 11,2 proc. visu lètinès dilgèlinès formų) pasireiškia 16-35 metu amžiaus grupejje. Gana dažna kontaktiné lètiné dilgèlinè, kurią sukelia kosmetikos (plaukų, nagu lakas, burnos skalaujamasis skystis, dantų pasta, kvepalai, rankų kremai, repelentai nuo vabzdžių) ir buitinès chemijos priemonès (muilas, skalbiamieji milteliai, valomosios priemonès), taip pat vilna, šilkas, profesinès aplinkos veiksniai, gyvūnų išskiriamos medžiagos. Ligos požymiai gali pasireikšti ne tik sąlyčio su medžiaga vietoje, bet ir sistemiškai.

\section{DIAGNOSTIKOS IR DIFERENCINĖS DIAGNOSTIKOS YPATUMAI}

Paprastai dilgèlinès diagnozė sunkumų nekelia - liga nustatoma remiantis išsamios anamnezès ir klinikinio (fizinio) paciento tyrimo duomenimis. Nemaža problemų kyla nustatant dilgèlinę sukeliančius (provokuojančius) veiksnius. Kiekvienam pacientui individualiai pagal spejjamą dilgèlinę sukèlusị veiksnį atliekami mèginiai su i̇tariamu fiziniu veiksniu, alergenu, vaistu ar maisto pseudoalergenu. Dažniausi laboratoriniai tyrimai: bendrasis kraujo tyrimas, eritrocitú nusèdimo greitis, C reaktyvusis baltymas, IgE. Tirti pradetas pacientas gydomas simptomiškai 4 savaites. Daugeliu atvejų dilgèlinè praeina savaime ar pašalinus ją skatinantị veiksnị. Jei liga tęsiasi ilgiau, pacientą reikia tirti nuodugniau: surenkama itin išsami maitinimosi istorija, atliekami išplèstiniai mėginiai su maisto ir vaistų alergenais, ieškoma lètinès infekcijos, neoplazinio proceso užuomazgų, slypinčios sisteminès ligos. Šiuo etapu gali būti atliekami tokie tyrimai: gastroskopija ieškoma Helicobacter pylori infekcijos, išmatų tyrimas dèl parazitų, ANA tyrimas. Papildomai galima atlikti maisto provokacinius méginius, paskirti eliminacinę dietą. Labai svarbu ištirti skydliaukès funkciją, ar nèra autoimuninès skydliaukès ligos, ypač žmonėms, turintiems nusiskundimų, būdingų hipotireozei. İodiniai mėginiai su autologiniu serumu gali sukelti odos reakciją, kai yra autoantikūnų prieš FcRI receptorius ar IgE (autoimuninès kilmès dilgèlinè). Odos biopsija atliekama tik tada, kai ligą sukèlusi priežastis vis dar neaiški, ir įtariamas dilgèlinis vaskulitas.

\section{GYDYMAS}

Dilgèlinès gydymu vadinamas ne vien vaistu vartojimas, bet visas kompleksas priemonių, kurios taikomos siekiant ligos priežasčių, mechanizmų, simptomų išvengti ar juos pašalinti.

\section{Sudedamosios gydymo dalys}

1. Dilgèlinę provokuojančių veiksnių vengimas, šalinimas. Jei ịtariama, kad vaistai provokuoja dilgèlinès simptomus, ju vartojimas turi būti visiškai nutrauktas, o jei jie būtini, pakeisti kitos grupès vaistais. Jei pacientas serga fizine dilgèline, svarbu mokyti pacientą, kaip kontroliuoti fizinių veiksnių poveikị kasdieniame gyvenime. Dažna lètinès dilgèlinès priežastis - natūralių maisto produktų ar juose esančiuc maisto priedų sukeliamos pseudoalerginès reakcijos. Tokiais atvejais turi būti skirta speciali dieta 3-6 mèn. Neretai lètinè dilgèlinè susijusi su lètinėmis uždegimo ar infekcinèmis ligomis, todèl gydant dilgèlinę pirmiausia svarbu tinkamai gydyti priežastines lètines ligas (H. pylori, bakterinis nazofaringitas, sinusitas, parazitų, pirmuonių infekcijos, išplitusi kandidozè, gastritas, refliuksinis ezofagitas, tulžies pūslès ar jos latakų uždegimai).

2. Medikamentinis gydymas (1 lentelè). Pirmaeiliai yra II kartos antihistaminiai vaistai (desloratadinas, feksofenadinas, levocetirizinas, cetirizinas, ebastinas, loratadinas). Naujausi geriamieji antros kartos antihistamininiai vaistai pasižymi ir 
1 lentelè. MEDIKAMENTINIS GYDYMAS

\begin{tabular}{|c|c|c|c|}
\hline Gydymas & Efektyvumas & Ilrodymų lygmuo & $\begin{array}{l}\text { Rekomendacijos } \\
\text { laipsnis }\end{array}$ \\
\hline $\begin{array}{l}\text { II kartos antihis- } \\
\text { tamininiai vaistai }\end{array}$ & & $1++$ & $A$ \\
\hline Cetirizinas* & ++ & $1+$ & $\begin{array}{l}\text { M. la Rosa ir kt., } \\
2001 \\
\text { S. Handa ir kt., } 2004 \\
\text { D. Breneman } 1996\end{array}$ \\
\hline Desloratadinas & ++ & $1+$ & $\begin{array}{l}\text { E. Monroe ir kt., } \\
2003 \\
\text { J. Ring ir kt., } 2001\end{array}$ \\
\hline Ebastinas & + & $1-$ & $\begin{array}{l}\text { B. Kalis1996 } \\
\text { J. Peyri ir kt., } 1991\end{array}$ \\
\hline Feksofenadinas & ++ & $1+$ & $\begin{array}{l}\text { M. Degonda ir kt., } \\
2002 \\
\text { M. Kawashima ir kt., } \\
2002 \\
\text { HS. Nelson ir kt., } \\
2000\end{array}$ \\
\hline Levocetirizinas* & ++ & $1+$ & A. Kapp ir kt., 2005 \\
\hline Loratadinas & ++ & $1+$ & $\begin{array}{l}\text { EW. Monroe } 1992 \\
\text { S. Belaich ir kt., } \\
1990\end{array}$ \\
\hline
\end{tabular}

*Slopina stipriau nei placebo.

Pagal Zuberbier et al. Allergy, 2006.

simptominiu (slopinančiu išsiskyrusių mediatorių poveikị audiniams ir organams), ir mediatorių išsiskyrimą iš putliųjų ląstelių bei bazofilų slopinančiu poveikiu. Antros kartos geriamieji antihistamininiai vaistai neslopina (desloratadinas, loratadinas, feksofenadinas) arba slopina menkai (cetirizinas). Šie vaistai gali būti vartojami ilgą laiką, o jų tikètinas nepageidaujamas poveikis minimalus (klinikiniu tyrimų duomenimis, artimas placebo poveikiui). Gydymo taktiką reikia peržiūrèti kas 3-6 mèn. Jei gydant iprastine antros kartos antihistamininiu vaistų doze klinikinis poveikis nepakankamas, prieš renkantis alternatyvų gydymo būdą, veiksmingiau ir saugiau (įrodyta klinikiniais tyrimais) padidinti antros kartos antihistamininių vaistų santraukose rekomenduojamą paros dozę iki keturių kartų.

Pirmos kartos antihistaminiai vaistai (chloropirami-

\section{CHRONIC URTICARIA}

\section{EDITA GASIŪNIENĖ, BRIGITA ŠITKAUSKIENE DEPARTMENT OF PULMONOLOGY AND IMMUNOLOGY KAUNAS UNIVERSITY OF MEDICINE}

Key words: chronic urtiaria, antihistamines, mast cell.

Summary. Chronic urticaria negatively impacts quality of life via sleep disruption, fatigue, social isolaton, energy loss, and emotional/sexual difficulties. Chronic urticaria is heterogeneous group of deseases that share a distinct skin reaction - the development of urticarial skin lession. Wheals with or without angioedema appear and peak in minutes to hours, ussually disappear within $24 \mathrm{~h}$ and repeats for more than 6 weeks. Chronic idiopathic urticaria is the diagnosis when the pathophysiological mechanism of persistent urticaria remains unclear; up to half of patients with chronic idiopathic urticaria has functional autoantibodies, which appear to induce mast cell degranulation. But our as medical doctors main task is to find the real cause of urticaria. Systemic histamine $\mathrm{H} 1$ receptor antagonists are central to the management of chronic urticaria. nas, klemastinas, difenhidraminas) dilgèlinei gydyti ilgą laiką buvo nevartojami, nes daro slopinamąji poveikį. Jų dažniausiai skiriama tada, kai naktị labai vargina niežulys. Deja, slopinimas lieka ir dieną, taigi pablogeja kasdienè veikla. Pirmenybè šiems vaistams (injekciju formos) teikiama tik tada, kai reikia greito sisteminio antihistamininio poveikio ir nèra galimybès skirti geriamųjų vaistų.

Gliukokortikosteroidu (prednizolono, hidrokortizono) lètinei dilgèlinei gydyti paprastai neskiriama, tačiau kai yra autoantikūnų prieš FcRI receptorius ar IgE arba lètinė dilgèlinè paūmèja, gali būti vartojami. Neskirtini ilgi kursai, nes simptomams slopinti paprastai reikia didelių vaisto dozių, kurios sukelia nepageidaujamą poveikị.

Kartais kartu su antros kartos antihistamininiais vaistais vartojami $\mathrm{H}_{2}$ receptoriu antagonistai (cimetidinas, ranitidinas) gali sustiprinti sunkios dilgèlinès gydymą.

Leukotrienų receptorių antagonistų (montelukasto), pasižyminčiuc silpnu uždegimą slopinančiu poveikiu, gali būti skiriama kartu su antros kartos antihistamininiais vaistais gydant sunkią arba aspirino bei maisto priedų sukeltą dilgélinę.

Psoralenas ir ultravioletiniai A spektro spinduliai (PUVA) sumažina putliųjų ląstelių skaičių dermoje, todèl gali būti vertingi gydant atsparios formos lètinę dilgèlinę. Gydoma 1-3 mèn. kartu su antihistamininiais vaistais.

Sunkia, ịprastiniam gydymui atsparia lètine dilgèline sergančius pacientus bandoma gydyti ciklosporinu, metotreksatu, dapsonu, sulfasalazinu, tačiau dažnai pasireiškia nepageidaujamas šiuc vaistuc poveikis.

Pavieniais atvejais gydant lètinę dilgèlinę, kai nustatyti aukšti autoantikūnų titrai, buvo veiksminga plazmaferezès, intraveninio imunoglobulino preparatai.

\section{LITERATŨRA}

1. Šitkauskienè B, Dubakienè $R$, Staikūnienè $J$ ir kt. Dilgèlinès diagnostiko ir gydymo rekomendacijos //Kaunas, 2006.

2. Zuberbier $T$, Bindslev-Jensen $C$, Canonica $W$ et al. EAACI/GA2LEN/EDF guideline: definition, classification and diagnosis of urticaria// Allergy 2006; 61:316-320

3. Zuberbier T, Bindslev-Jensen C, Canonica W et al. EAACI/GA2LEN/EDF guideline: management of urticaria// Allergy 2006; 61:321-331.

4. Zuberbier T. Urticaria//Allergy 2003; 58:1224-1234

5. Hein R. Chronic urticaria: impact of allergic inflamation//Allergy 2002; 57(Suppl.75): 19-24

6. Kaplan A.P. Chronic urticaria and angioedema//N.Engl.J.Med. 2002; 346:175-179

7. Greaves M. Chronic urticaria//J.Allergy.Clin.Immunol. 2000; 105:664 672.

8. O'Donell BF, Lawlor F,Greaves MW. The impact of chronic urticaria on the quality of life// Br J Dermatol 1997; 136:197-201.

9. Ring J, Brockow $\mathrm{K}$, Ollert $\mathrm{M}$ et al. Antihistamines in urticaria//Cin Exp Allergy 199;29:31-37.

10. Wedi B, Raap U, Kapp A. Chronic urticaria and infections//Curr Opin Allergy Clin Immunol 2004; 4:387-396.

11. Wedi B, Kapp A. Helicobacter pylori infection in skin diseases: a critical appraisal//Am J Clin Dermatol. 2002; 3:273-282. 